\title{
Knowledge levels of pediatric surgeons about child abuse and neglect: A survey study
}

\section{Çocuk cerrahlarının çocuk istismarı ve ihmaliyle ille illgili bilgi düzeyleri: Anket çalışması}

\author{
Levent Cankorkmaz ${ }^{1}$, Selma Cetinkaya², Gökhan Köylüoğlü ${ }^{3}$, Sanem Nemmezi Karaca ${ }^{4}$
}

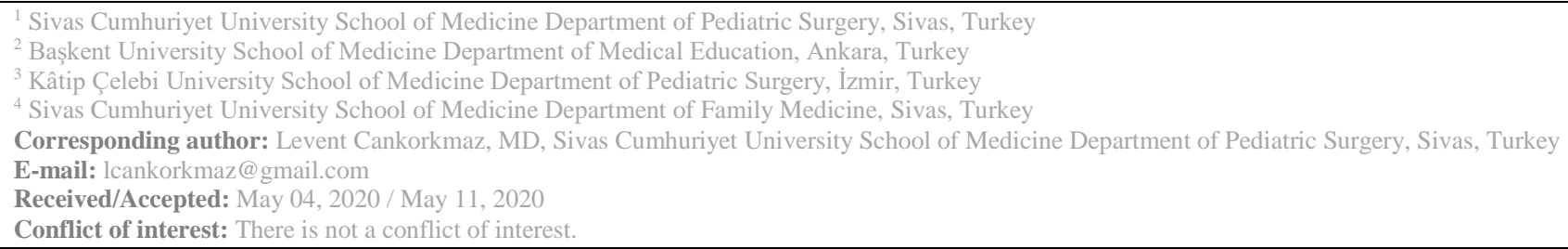

\section{SUMMARY}

Objective: The aim of the present study was to determine about knowledge level and opinions of pediatric surgeon' about child abuse and neglect and to draw attention to this issue.

Method: The research was conducted as a descriptive study among those who attended the 28th National Congress of Pediatric Surgery and agreed to participate in the research $(n=56)$. Data were collected using the "Questionnaire Form" and analyzed using number, percentage, mean, standard deviation and chi-square test.

Results: The average of correct answers of the physicians participating in the study was $23.9 \pm 7.6$. No statistically significant difference was found between the correct response averages of physicians who had previously received training and the correct response average of physicians who had not received education $(\mathrm{p}=0.966)$. It was seen that $89 \%$ of the participants had a desire to obtain information on this subject.

Conclusions: According to the findings obtained as a result of the research, we think that pediatric surgeons need more information about child abuse and neglect, and in order to provide early diagnosis, faculty education and in-service training programs should be given importance.

Keywords: Child abuse,neglet,education

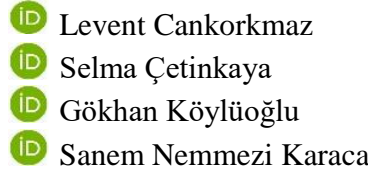

ORCID IDs of the authors: L.C. 0000-0003-1525-1470 S.Ç. 0000-0003-4231-3980 G.K. 0000-0002-1140-169X S.N.K. 0000-0002-4853-8366

\section{ÖZET}

Amaç: Bu çalışmanın amacı, çocuk cerrahının çocuk istismarı ve ihmali hakkında bilgi düzeyini ve görüşlerini belirlemek ve bu konuya dikkat çekmekti.

Yöntem: Araștırma, 28. Ulusal Çocuk Cerrahisi Kongresi'ne katılan ve araștırmaya katılmayı kabul edenler arasında tanımlayıcı bir çalışma olarak yürütülmüştür $(n=56)$. Veriler "Anket Formu” kullanılarak toplanmış ve sayı, yüzde, ortalama, standart sapma ve ki-kare testi kullanılarak analiz edilmiștir.

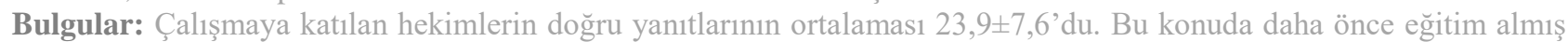
hekimlerin doğru yanıt ortalamalarıla, eğitim almamış hekimlerin doğru yanıt ortalaması arasında istatistiksel olarak

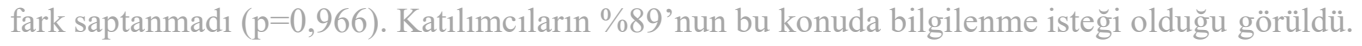

Sonuç: Araştırma sonucunda elde edilen bulgulara göre, çocuk cerrahlarının, çocuk istismarı ve ihmali konusunda daha fazla bilgilenmeye gereksinimleri olduğu, erken tanı sağlamak için fakülte eğitimi ve hizmet içi eğitim programlarına önem verilmesi gerektiğini düşünmekteyiz.

Anahtar sözcükler: Çocuk istismarı, ihmal, eğitim 


\section{INTRODUCTION}

The World Health Organization (WHO) defines child maltreatment as an act that includes "all forms of physical and emotional ill-treatment, sexual abuse, neglect, and exploitation that results in actual or potential harm to the child's health, development or dignity" ${ }^{1}$.

The duties of physicians in respect of child abuse can be regarded as keeping the probability of this diagnosis in mind for every child they encounter, having current knowledge about the topic and managing the cases according to the cultural and legal norms of the country ${ }^{2}$. Each year in the United States, Child Protective Service agencies receive more than 3 million reports of suspected child maltreatment and investigate more than 2 million of these reports; more than 650,000 children are substantiated by child welfare as maltreatment victims ${ }^{3}$.

The aim of this study, was to determine the knowledge of child abuse and neglect of pediatric surgeons who provide services to children, and to evaluate whether their demographic characteristics and occupational experience had any effect on the diagnosis of child abuse to draw attention to this issue.

\section{MATERIAL AND METHODS}

Fifty-six volunteers pediatric surgeons who applied to 28th National Congress of Pediatric Surgery was included in our research, and a detailed questionnaire was applied. Ethics committee approval was received for this descriptive study from the Cumhuriyet University School of Medicine. Permission for the study was obtained from congress organization. Informed consent was obtained from the participants.

To the authors' knowledge, there is no valid and reliable measure of knowledge regarding the on the child neglect and abuse of physicians. The questionnaire was created by researchers by scanning the literature as two parts. The first part included questions about demographic characteristics (Health Centers, occupational experience, training on child abuse) and the frequency of encountering child physical abuse cases, since that is the most easily diagnosed and proven form of abuse. The second part consisted of a questionnaire with 40 items prepared by authors, including questions about their knowledge on child abuse and their opinion about the procedures during the follow-up of these cases.

Frequency and chi-square tests were used to analyze the data. Levels of $\mathbf{p}<0.05$ were accepted as being statistically significant values. Statistical analyses were performed using Statistical Package for Social Sciences (SPSS) version 10.0 (SPSS Inc., Chicago, Illinois, USA).

Table 1: Characteristics of the participating Pediatric Surgeons

\begin{tabular}{|l|c|c|}
\hline \multicolumn{1}{|c|}{ Characteristics } & n & \% \\
\hline Occupational experience & 13 & 23.2 \\
$5-10$ & 19 & 33.9 \\
$11-20$ & 18 & 32.2 \\
$>21$ & 6 & 10.7 \\
\hline Assistants & 12 & 21.4 \\
Specialists & 24 & 42.9 \\
Faculty members & 20 & 35.7 \\
\hline Health Centers & 17 & 30.4 \\
State Hospital & 37 & 66.0 \\
University & 2 & 3.6 \\
Private & 56 & 100 \\
\hline Total & & \\
\hline
\end{tabular}




\section{RESULTS}

Fifty-six Pediatric Surgeons participated in the study. The duration of clinical experience, duties and institutions of pediatric surgeons are given in Table 1. Of the 56 pediatric surgeons, 17 (30.4\%) participate working in the State Hospital, 37 (66\%) in the university hospital, $2(3.6 \%)$ in the private sector. Overall, $12(21.4 \%)$ of the participants were assistants, 24 (42.9\%) were specialists, 20 (35.7\%) were faculty members.

Physicians who participated in the study, $78.6 \%$ married, $21.4 \%$ single; $58.9 \%$ had children $41.1 \%$ had no children. Of those who had children, $27.2 \%$ had boys, $36.4 \%$ had girls and $36.4 \%$ had both girls and boys.

$62.5 \%$ of the participant found the level of knowledge on this subject insufficient. $73.2 \%$ of the participants stated that they knew what to do when they suspect a child neglect or abuse. Only $14.3 \%$ knew the unit to assess suspicion of child abuse in hospital.

A total of $78.6 \%$ of the physicians reported that they had encountered physical child abuse or neglect victims at least once in their occupational life. $10.7 \%$ of participants encountered one case a week, $23.1 \%$ had encountered one case a month abused children. $57.1 \%$ of participants reported less than one case a month. Also, $8.9 \%$ had not encountered any physically abused children.

Survey questions and answers are given in Table 2. The correct answers to the questions of the physicians were as follows: (min: 13, max: 27 and median: 22). Correct answers to the questions are summarized in Graphic 1.

The difference between the answers given to the twenty-eighth question was statistically significant compared to the institutions of studied, and it was observed that those working at the university answered the question at a significantly higher rate compared to those working at the public hospital $(\mathrm{p}=0.031)$. Frequency of faculty members to know question 16 was higher than other physicians $(\mathrm{p}=$ $0.017)$.

When the correct answers of the physicians were compared according to their occupational experience, the frequency of the physicians with 5 years and more occupational experience to the 5th and 16th questions was significantly higher than the other groups $(\mathrm{p} 1=0.006, \quad \mathrm{p} 2=0.034$ respectively).

$53.6 \%$ of the physicians had never received any training on child abuse and neglect. The average of correct answers of the physicians participating in the study is $23.9 \pm 7.6$. The average of correct answers of physicians trained on this subject is 23.8 \pm 10.2 , and untrained physicians are $23.9 \pm 4.4$ and there was no statistical difference between them. $(\mathrm{t}=-0.043, \mathrm{p}=0.966)$.

It was observed that physicians who were not trained about child abuse and neglect incorrectly answered the 27th question at a statistically significant level $(p=0.001)$. It was seen that most of the trained answered the 35th question incorrectly $(\mathrm{p}=0.009)$.

$62.5 \%$ of the participants express the level of knowledge on child abuse and neglect insufficient. In addition, compared to those who thought that physicians who found their knowledge of child abuse and neglect inadequate were sufficient, the rate of correct answer to the 5th question was higher $(p=0.028)$. It was observed that most of the physicians, who stated that they knew the things to be done in case of abuse, they answered the 21 question incorrectly.

$80 \%$ of those who did not encounter child abuse and neglect had answered the 35th question incorrectly and this was statistically significant $(\mathrm{p}=$ 0.046). 
Table 2: The list of Physicians' response to survey.
1 True
2 No idea
3 False

\section{QUESTIONS}

1. The presence of lesions in the head / neck region of the child, such as zygomatic or mandible, is a sign of physical abuse.

2. Lesions are most commonly in the chest, back, calves, genital area, upper arm, face, upper lip, palate and eyes.

3. In children, accident-related injuries mostly occur in the front part of the body.

4. In children who have suffered physical abuse, burns are more common on the feet, buttocks, lower parts of the arm and leg.

5. Socks and glove-style burns occur mostly by accident.

6. In the studies carried out, it was determined that the parents who used the most abuse and violence were the parents.

7. Abuse should be considered in children especially if there are many complex and collapsing fractures in long bones.

8. Sexual abuse is certain when the sexually transmitted disease is detected in the child.

9. Genital area, mouth, arm nape or legs ecchymosis and abrasions should be suggestive of sexual abuse.

10. Sexual abuse is the most easily diagnosed form of abuse.

11. The child may also have been sexually abused without physical contact.

12. A significant proportion of children who have been sexually abused have also been physically abused.

13. Children's growth-development retardation, vaccination delay, poor hygiene should be thought to be neglected.

14. Children who are abused and neglected may exhibit hyperactive behaviors.

15. Children who are abused and neglected may exhibit fearful behavior from their parents and other adults.

16. The most important finding in shaken baby syndrome is obtained by "eye examination".

17. The child who has completed his toilet training should start wetting the gold again, suggesting that he may have been abused or neglected.

18. Children who have been abused and neglected may show introversion, and often cannot communicate eye-to-eye.

19. In cases such as injury, fracture, the inconsistency of the story told by the family should bring to mind physical abuse.

20. Parents who are abused and neglected in their childhood refrain from abusing and neglecting their children.

21. The child should not be distant from his family while performing laboratory tests and radiological examinations for suspected child abuse and neglect.

22. Maternal age is not important in child abuse and neglect.

23. Parent's loss of social support leads to child abuse and neglect.

24. Parent's mental problems are the most important risk for child abuse and neglect.

25. The gender of the child is not important in abuse and neglect.

26. Children who are overly active are more likely to experience physical abuse.

27. A mother's difficult pregnancy or difficult birth affects her child abuse or neglect.

28. The mother's frequent complaints from the child should be suggestive of abuse.

29. Babies are less likely to be abused.

30. The income level of the family and the number of children is an important factor in abuse and neglect.

31. Child abuse and neglect is not found in upper socioeconomic families.

32. Medical evaluation should be done in a room that is arranged like a game room.

33. Consent is required for the interview.

34. The interview should be recorded (voice, video, and camera).

35. A "Forensic interview" should be held in order to ensure communication, coordination, reduce the number of interrogations of the child, and increase the diagnostic ability of the team investigating the event.

36. If the child is not very young, the family should be kept outside during the interview.

37. When communicating with the child, they should speak childish and make statements that indicate that we are surprised or pity her.

38. It is enough to take the anamnesis from parents.

39. In case of doubt, necessary samples (such as vaginal, anal swabs) should be taken for diagnosis.

40. The international agreement on child abuse and neglect is the "Convention on the Rights of the Child". *** Correct answers to the questions

\begin{tabular}{|c|c|c|}
\hline 1 & 2 & 3 \\
\hline 64.3 & 25.0 & 10.7 \\
\hline 89.3 & 10.7 & - \\
\hline 50.0 & 33.9 & 16.1 \\
\hline 58.9 & 30.4 & 10.7 \\
\hline 32.1 & 28.6 & 39.3 \\
\hline 67.9 & 28.6 & 3.5 \\
\hline 66.1 & 25.0 & 8.9 \\
\hline 57.1 & 12.5 & 30.4 \\
\hline 89.3 & 8.9 & 1.8 \\
\hline 25.0 & 17.9 & 57.1 \\
\hline 83.9 & 14.3 & 1.8 \\
\hline 75.0 & 16.1 & 8.9 \\
\hline 87.5 & 8.9 & 3.6 \\
\hline 51.8 & 33.9 & 14.3 \\
\hline 89.3 & 10.7 & - \\
\hline 55.3 & 41.1 & 3.6 \\
\hline 69.7 & 19.6 & 10.7 \\
\hline 78.6 & 17.9 & 3.6 \\
\hline 92.9 & 7.1 & - \\
\hline 16.1 & 35.7 & 48.2 \\
\hline 28.6 & 26.8 & 44.6 \\
\hline $\begin{array}{l}8.9 \\
\end{array}$ & 33.9 & 57.1 \\
\hline 64.3 & 33.9 & 1.8 \\
\hline 87.5 & 12.5 & - \\
\hline 39.3 & 16.1 & 44.6 \\
\hline 21.4 & 39.3 & 39.3 \\
\hline 28.6 & 53.6 & 17.8 \\
\hline 50.0 & 37.5 & 12.5 \\
\hline 10.7 & 16.1 & 73.2 \\
\hline 62.5 & 23.2 & 14.3 \\
\hline 1.8 & 10.7 & 87.5 \\
\hline 75.0 & 19.6 & 5.4 \\
\hline 50.0 & 35.7 & 14.3 \\
\hline 73.2 & 23.2 & 3.6 \\
\hline 57.2 & 35.7 & 7.1 \\
\hline 83.9 & 12.5 & 3.6 \\
\hline 12.5 & 26.8 & 60.7 \\
\hline 3.6 & 7.1 & 89.3 \\
\hline 87.5 & 12.5 & - \\
\hline 55.4 & 41.1 & 3.6 \\
\hline
\end{tabular}




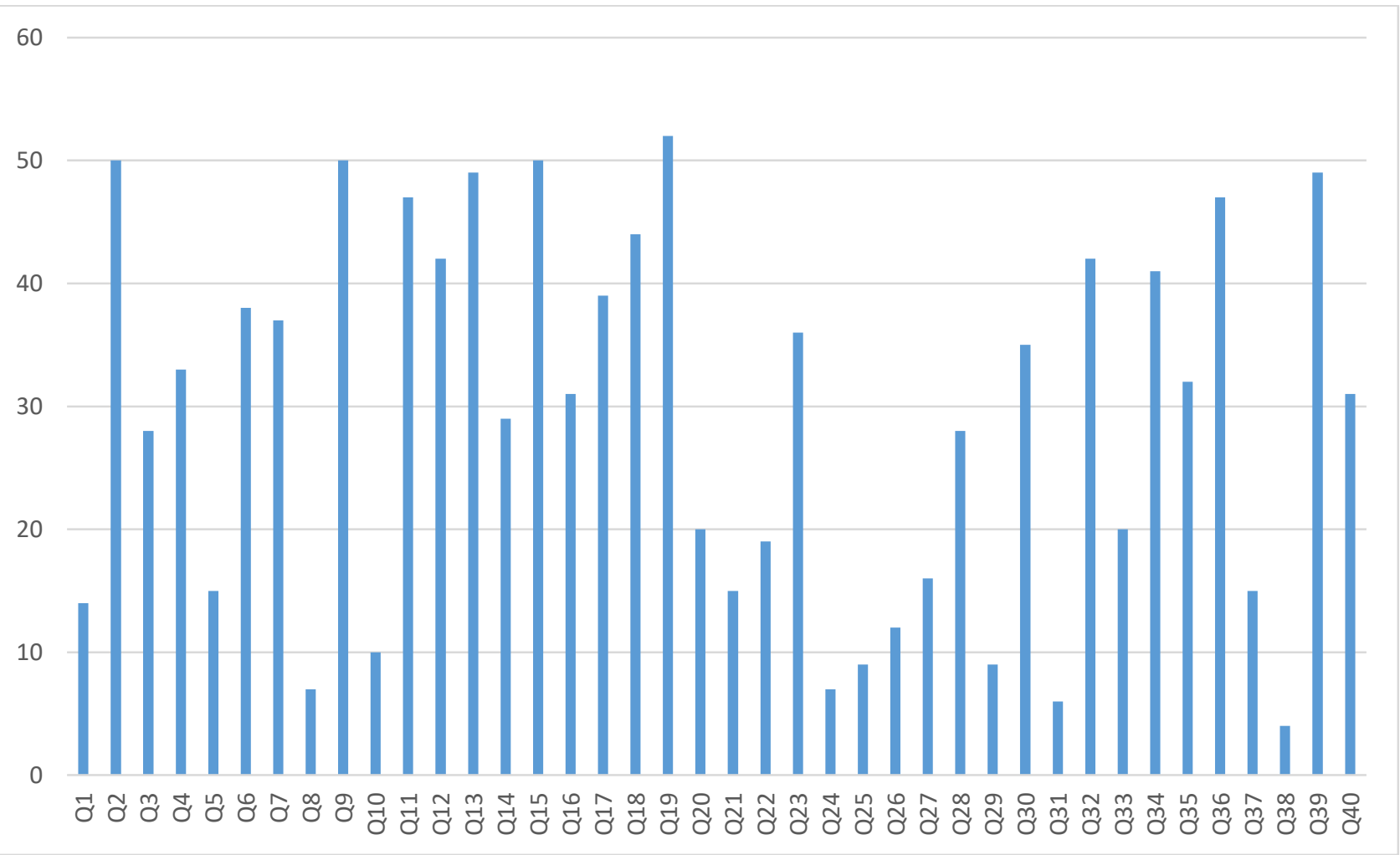

Graphic 1: The rates of correct answer of questions.

\section{DISCUSSION}

Child abuse and neglect cannot be detected unless it is taken into consideration. Identifying and ensuring the health of abused and neglected children is challenging. Child victims are often preverbal, too severely injured, or too frightened to disclose, and injuries can be nonspecific.

Although the first step in the diagnosis of abuse is keeping it in mind as a diagnostic possibility, it should not be forgotten that the level of knowledge of the professionals is crucial for it is management. In the study group, there was no statistically significant difference of correct response rate of assistants, specialists and residents.

Even today many physicians are reluctant to report abuse cases. The reluctance of physicians to report has been documented in previously published reports $4,5,6$. In another publication, $43 \%$ of paediatricians and family physicians stated that they were not comfortable with reporting physical child abuse cases ${ }^{7}$.

Reasons for hesitating to report child abuse cases could be: not having information about family dynamics, inadequate training about the topic, avoiding the emotional burden of the situation since there is no effective system to help these children and a combination of all these factors, according to the work of Demirçin et al. ${ }^{6}$.

In a study in the USA, showed that a significant number of paediatricians were reporting suspected child abuse and $96 \%$ had reported a case at least once ${ }^{8}$. In our study, $78.6 \%$ of the pediatric surgeons reported that they had encountered physical child abuse or neglect victims at least once in their occupational life.

$73.2 \%$ of the pediatric surgeons stated that they knew what to do when they suspect a child neglect or abuse although only $14.3 \%$ knew the unit to assess suspicion of child abuse in hospital.

While $62.5 \%$ of the respondents found the level of knowledge in this regard insufficient, there was no statistical difference in the correct response rates between educated physicians and untrained physicians. This finding suggests that information learned during medical training can be forgotten if not supported by postgraduate training.

The overall correct response rates did not differ according to the occupational experience, or age of the participants.

It was concluded that this issue should be given importance in the in-service training programs and assistant training for the early recognition of abuse 
and neglect, findings of the research Pediatric surgeons need more information about child abuse and neglect. Pediatric surgeons who have a high probability of encountering child abuse victims need to be trained both theoretically and practically.

It should be ensured that physicians understand the importance of this issue. Due to their position, Pediatric Surgeons should try to focus more on this problem and play a role in the early diagnosis and treatment of these children.

\section{REFERENCES}

1. Srivastava K, Chaudhury S, Bhat P. S, Patkar P. Child sexual abuse: the suffering untold. Ind Psychiatry J. 2017 Jan-Jun; 26(1): 1-3. doi: 10.4103/ipj.ipj_83_17

2. Schilling EA, Aseltine RH, Jr, Gore S. Adverse childhood experiences and mental health in young adults: a longitudinal survey. BMC Public Health. 2007; 7:30.

3. U.S. Department of Health and Human Services, Administration for Children and Families, Administration on Children, Youth and Families, Children's Bureau. 2012. Child maltreatment 2011. Available at:

http://www.acf.hhs.gov/programs/cb/resea rch-data-technology/statistics- research/child-maltreatment. Accessed April 23, 2014.

4. Açık Y, Deveci SE, Oral R. Level of knowledge and attitude of primary care physicians in Eastern Anatolian cities in relation to child abuse and neglect. Prev Med 2004;39:791-7.

5. Canbaz S, Turla A, Aker S, Peşken Y. Samsun merkez sağlık ocaklarında görev yapan pratisyen hekimlerin çocuk istismarı ve ihmali konusunda bilgi ve tutumları. STED 2005;14:241-6.

6. Demirçin S, Tütüncüler A, Aslan F, Velipaşaoğlu Güney $S$, Atılgan $M$, Gülkesen H. The Knowledge Level and Opinions of Physicians about the Medical and Legal Procedures Related to Physical Child Abuse. Balkan Med J. 2017 Apr 5; 34(2): 140-146. doi: 10.4274/balkanmedj.2015.1195.

7. Offer-Shechter S, Tirosh E, Cohen A. Physical abuse-physicians knowledge and reporting attitude in Israel. Eur J Epidemiol 2000;16:53-8.

8. Theodore AD, Runyan DK. A survey of pediatricians' attitudes and experiences with court in cases of child maltreatment. Child Abuse Negl 2006; 30:1353-63. 